\title{
TWO CASE REPORTS OF COVID-19 PATIENTS WITH CONCURRENT INTRACRANIAL HEMORRHAGE
}

\author{
IKI OLGU SUNUMU: INTRAKRANIAL KANAMANIN EŞLIK ETTIĞi COVID-19 VAKALARI
}

\author{
Pınar VARGÜN¹ (D), Musa KAYA ${ }^{1}$ (D) \\ 'Zonguldak Ataturk State Hospital, Department of Emergency Medicine, Zonguldak, Turkey
}

ORCID IDs of the authors: P.V. 0000-0003-0055-7741; M.K. 0000-0003-4962-2575

Cite this article as: Vargun P, Kaya M. Two case reports of covid-19 patients with concurrent intracranial hemorrhage. J Ist Faculty Med 2021;84(3):439-42. doi: 10.26650/IUITFD.2020.0097

\begin{abstract}
COVID-19, of which unprecedented complications are constantly emerging, still continues to be the leading problem all over the world. As previously reported, neurological manifestations are some of the complications seen in novel coronavirus disease. Neurological complications are known to vary widely, including intracerebral hemorrhage. In this study, we intended to report two COVID-19 cases with concurrent intracerebral hemorrhage. In these case reports, we aimed to highlight the importance of being aware of neurological manifestations in COVID-19 patients.
\end{abstract}

Keywords: COVID-19, neurological complications, intracranial hemorrhage

\section{INTRODUCTION}

The Coronavirus disease 2019 (COVID-19) pandemic, caused by the novel severe acute respiratory syndrome coronavirus 2 (SARS-CoV-2) which was initially identified in China in December 2019 and expeditiously spread across the world, continues to be a public health problem. The disease can be severe and even mortal in older people and in those with underlying chronic disease. Mortality rate is $2-3 \%$ worldwide with an apparent variation between countries. Supportive and empirical treatments are recommended at present and specific treatment and/or vaccine are not yet available. (1)

Although the most common symptoms are known to be related with the respiratory system, it has been revealed that some COVID-19 cases can present with extrapulmonary manifestations. Moreover, some COVID-19 patients

\section{ÖZET}

Sürekli olarak yeni komplikasyonlarla gündeme gelen COVID-19, tüm dünyada hala önde gelen sorun olmaya devam ediyor. Daha önce bildirildiği gibi, nörolojik belirtiler, yeni coronavirüs hastalığında görülen komplikasyonlardan bazılarıdır. Nörolojik komplikasyonların, intrakraniyal kanamalar da dahil olmak üzere geniş ölçüde çeşitlilik gösterdiği bilinmektedir. Bu çalışmada, eş zamanlı olarak intrakraniyal kanaması da olan iki COVID-19 vakasını paylaşmak istedik. Bu vaka sunumları ile COVID-19 hastalarında nörolojik belirtilerin farkında olmanın önemini vurgulamayı amaçladık.

Anahtar Kelimeler: COVID-19, nörolojik komplikasyonlar, intrakraniyal kanama

Corresponding author/iletişim kurulacak yazar: pinarakhanli@gmail.com

Submitted/Başvuru: 07.08.2020 • Revision Requested/Revizyon Talebi: 07.09.2020 •

Last Revision Received/Son Revizyon: 24.12.2020 • Accepted/Kabul: 15.01.2021 • Published Online/Online Yayın: 17.03 .2021 


\section{CASE PRESENTATION}

Case 1: A 56-year-old male patient with no co-existing disease was admitted to the Emergency Department of Zonguldak Ataturk State Hospital following a weakness of the left side of the body and cough. It was found out that the patient didn't apply to another hospital for these complaints and had no a history of using anticoagulant or antiaggregant medications. At the time of the admission, vital signs were as follows: Glasgow coma score (GCS):14, blood pressure (BP):180/90 $\mathrm{mmHg}$, respiratory rate (RR): $16 / \mathrm{min}$, oxygen saturation (SpO2): 98\% heart rate (HR): 101/min and body temperature (BT):37.2. On neurological exam, his mental status was normal. There was no speech disturbance, neglect or visual field cut but a 3/5 left-sided hemiparesis was present. Eye movements and pupils were normal. He had a slight left nasolabial fold flattening. After the patient underwent a brain computed tomography (CT) scan, an intracranial hemorrhage $(26 \times 13 \mathrm{~mm})$ at the level of the pons was noticed (Figure 1). A chest CT scan was taken simultaneously and bilateral peripherally located ground glass opacity was detected in the lungs of the patient (Figure 1).

The patient was hospitalized in the intensive care unit (ICU). Clarithromycin, meropenem, hydroxychloroquine and favipiravir were administered after admission to the ICU. However, since the acute phase markers were inclined to increase, clarithromycin was stopped and teicoplanin was started. Despite being elevated at admission, his blood pressured remained within normal range during his follow-up. The result of RT-Polymerase Chain Reaction (RT-PCR) test of the patient was detected to be positive. D-dimer was determined to be elevated with a level of $9,475 \mu \mathrm{g} / \mathrm{mL}$ (reference range 0-500 $\mu \mathrm{g} / \mathrm{mL}$ ) following mea-

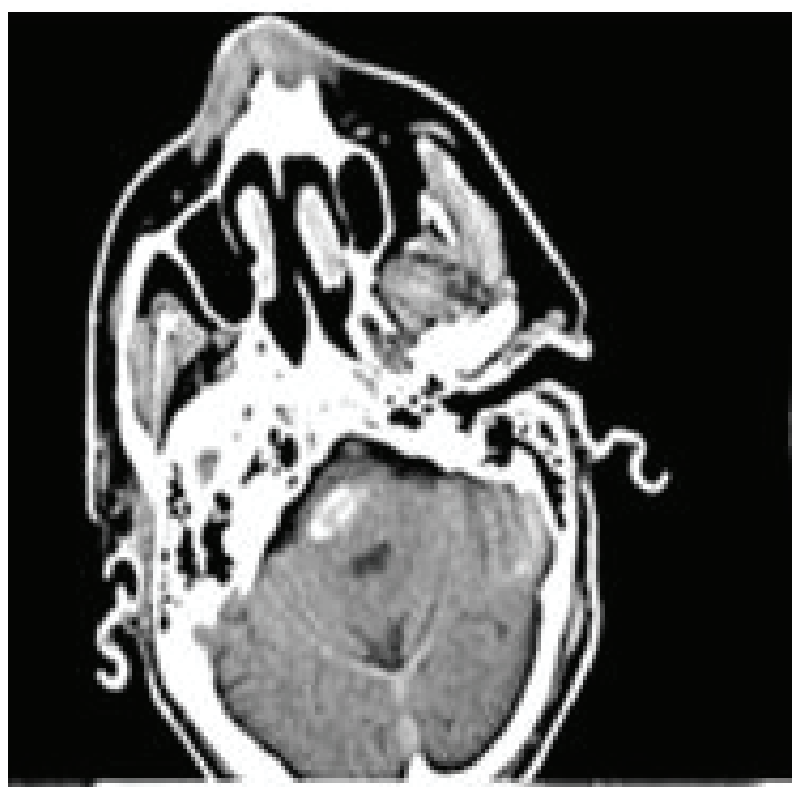

Figure 1: Brain CT scan image of the $1^{\text {st }}$ case surement in the ICU. A mild thrombocytopenia was present (126,000 per microliter). International normalized ratio (INR), protrombin time (PT) and activated partial thromboplastin time (aPTT) were found to be in the normal range $(1,11$ and 24 respectively). The level of ferritin $(1271 \mu \mathrm{g} / \mathrm{L})$ was above the normal range $(30-400 \mu \mathrm{g} / \mathrm{L})$. Unlike ferritin and D-dimer results, C-reactive protein value $(4 \mathrm{mg} / \mathrm{L}$, at admission) and fibrinogen (287 $\mathrm{mg} / \mathrm{dl}$, at admission) remained in the normal range during the follow-up. During his stay in the ICU, the patient had epileptic seizures. Endotracheal intubation was required after the deterioration of the paitent's neurological condition with low GCS in the $28^{\text {th }}$ day of the admission. The patient died of multiple organ failure at the end of the $41^{\text {st }}$ day.

Case 2: A 54-year-old male patient with a medical history of diabetes mellitus was brought to the Emergency Department of Zonguldak Ataturk State Hospital because of complaints such as nausea, vomiting, fever and severe headache. He didn't apply to another hospital earlier. It was elicited that he didn't use any blood thinners in his lifetime. At the time of the admission, vital signs were as follows: GCS:15, BP:130/80 mmHg, RR:18/min, SpO2: 100\%, HR: 88/min and BT: 37.8. On neurological exam, his mental status was normal. There was not any speech disturbance, limb weakness, neglect or visual field cut. Cranial nerve examination was normal. Cerebellar examination revealed that the patient had right-sided dysdiadochokinesia. Right intracerebellar hematoma with a size of $40 \times 29 \mathrm{~mm}$ was detected on brain CT scan (Figure 2). The chest CT scan taken simultaneously showed bilateral, peripheral and basal predominant ground glass (Figure 2).

The patient was admitted to the ICU. He was started on antibiotics and hydroxychloroquine. The patient tested posi-

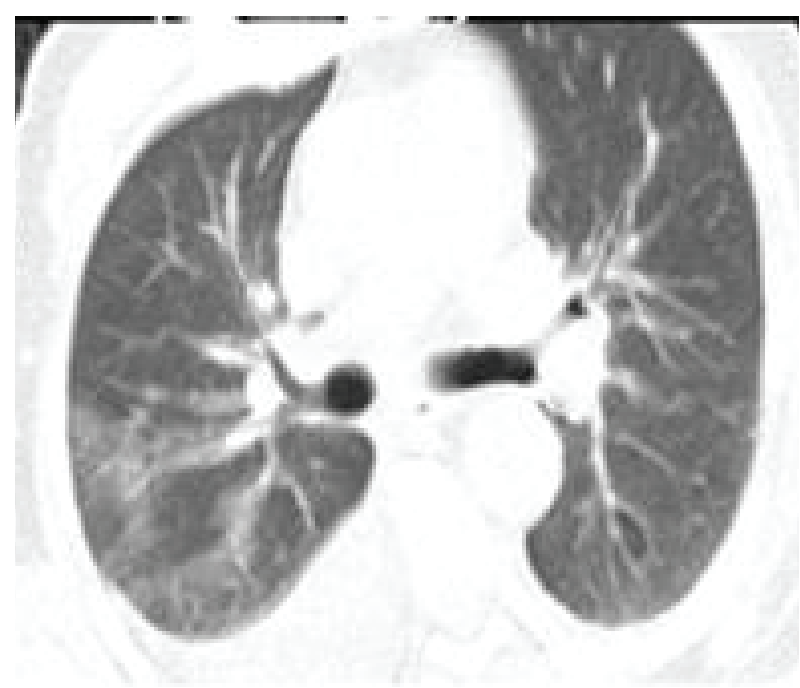

Figure 2: Chest CT scan image of the $1^{\text {st }}$ case 


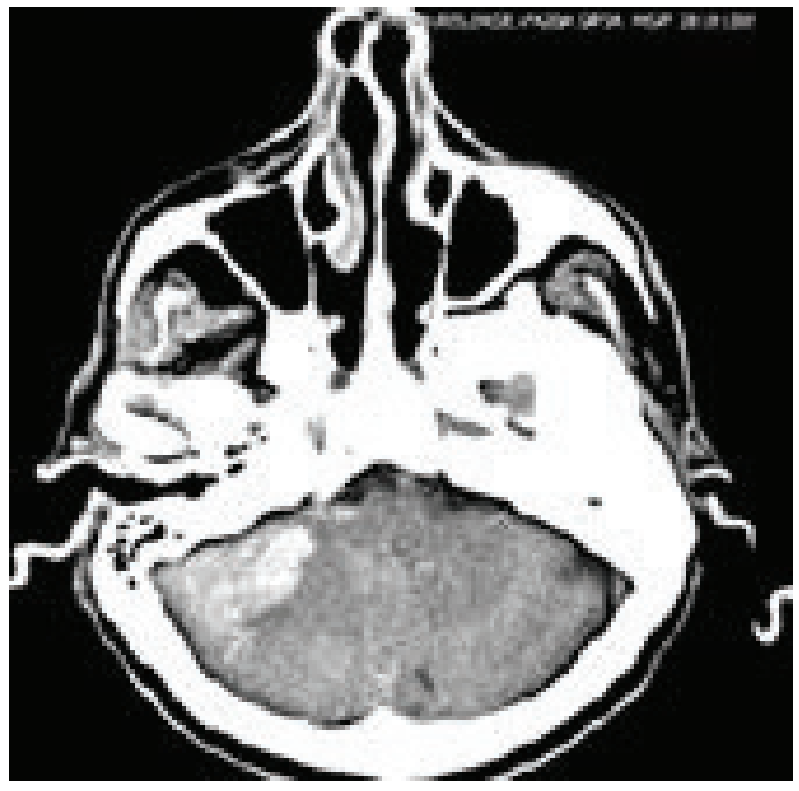

Figure 3: Brain CT scan image of the $2^{\text {nd }}$ case

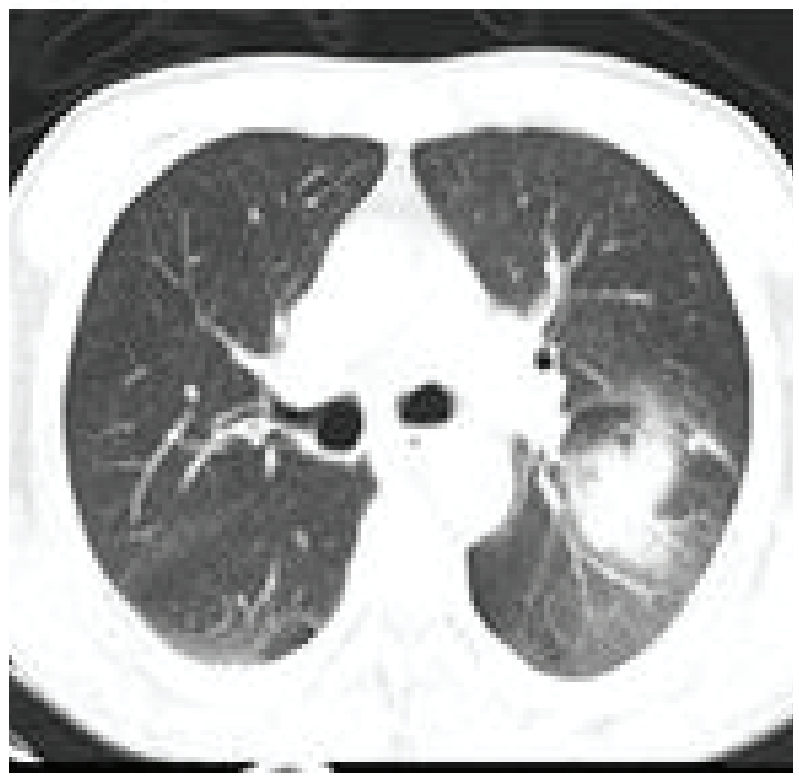

Figure 4: Chest CT scan image of the $2^{\text {nd }}$ case

tive for Covid-19. D-dimer level was found to be elevated with a value of $1,249 \mu \mathrm{g} / \mathrm{mL}$ in the beginning and began to decrease starting from the $2^{\text {nd }}$ day in the ICU. The platelet count was found to be slightly low (134,000 per microliter). INR, PT and aPTT were found to be in the normal range $(0.9,11$ and 26 respectively). Ferritin $(44 \mathrm{ng} / \mathrm{ml})$ and $\mathrm{C}$-reactive protein $(0 \mathrm{mg} / \mathrm{L})$ levels were within normal ranges. The patient was discharged with full recovery after firstly being transferred to a regular hospital room from the ICU.

Written informed consent was obtained from both patients.

\section{DISCUSSION}

As a global public health problem, COVID-19 infection, which continues to be the major issue all over the world, almost every day initiates discussions regarding the unknown aspects of the condition. There have been discussions about the involvement of the central nervous system in this disease considering previously reported various neurological complications in COVID-19 patients $(4,5)$. A broad-spectrum of neurological complications such as ischemic stroke, intracerebral hemorrhage, Guillain-Barre Syndrome, encephalitis, epilepsy and acute transverse myelitis have been reported in COVID-19 patients (6). Moreover, It has been suggested that neurological manifestations may even precede typical symptoms such as fever, cough and dyspnea in certain cases (6). In this study, we aimed to underline the fact that mortal neurological complications are most likely to be encountered in COVID-19 infection as we have detected intracerebral hemorrhage in two male patients aged 54 and 56 with COVID-19 (7). Several assumptions have been made about the potential mechanisms and facilitating factors in occurrence of such complications in this novel coronavirus disease. Although the typical targets of the coronaviruses are known to be the respiratory system, the fact that attachment of SARS-CoV-2 to the cells occurs through angiotensin converting enzyme-2 (ACE-2) and certain cells in the central nervous system have these receptors, suggest ACE-2 mechanism to have a role in neurological involvement in Covid-19 infection (8). In addition to COVID-19 cases with concurrent intracerebral hemorrhage, complications such as ischemic stroke (9) and cerebral venous thrombosis (10) have also been reported. Apart from ACE-2 receptor mechanism, it has also been postulated that neurological complications in novel coronavirus disease are possible to be originated from direct damage of infectious agents, an inflammatory process caused by these agents or other unexplained means. Moreover, these possible mechanisms may play a role in both ischemic and hemorrhagic strokes (11). Some findings regarding endothelial cell damage and vasculitis shown in some autopsy studies have been considered to explain the occurrence of ischemic stroke and intracranial hemorrhage in COVID-19 infection (12). In addition, coagulopathy proven with elevated D-dimer levels and thrombocytopenia has been shown in COVID-19 patients. It has been concluded that coagulopathy may be one of the reasons of neurological complications in novel coronavirus infection (13).

The main risk factors for intracranial hemorrhage are known to be hypertension, hypercholesterolemia, diabetes mellitus, smoking, alcohol and illegal drugs. Older people are more at risk than young people (14). In a case report, a 79-year-old man with no history of risk factors, such as anticoagulant therapy, was found to have a mas- 
sive intracerebral hemorrhage detected synchronously with COVID-19 (3). Benger et al. reported a case series with 5 patients with $\mathrm{ICH}$ and COVID-19. All the patients were relatively young. However, three of them were on anticoagulant therapy prior to COVID-19 and the other 2 patient received low dose anticoagulant treatment as a prophylaxis for thrombotic manifestations of COVID-19 (15). COVID-19 cases with or without risk factors have been reported to suffer from neurological complications such as intracerebral hemorrhage (16). Thus, it still remains unclear whether there is a causative link between intracerebral hemorrhage and novel coronavirus diseases. In our study, the 56-year-old patient did not have any co-existing disease and the other patient had only diabetes mellitus. Neither patient had a history of smoking or alcohol consumption. Both had coagulopathy evidence with elevated D-dimer and thrombocytopenia in accordance with prior studies. Considering one of our patients had no risk factors, the other patient had only one and both of them were at a relatively young age, the culprit in emergence of intracerebral hemorrhage may be conceived to be associated with COVID-19 infection itself instead of being coincidental. But it would be too hypothetical to conclude this without firther evidence.

\section{CONCLUSION}

In this case report of two COVID-19 patients with intracerebral hemorrhage, we aimed to emphasize that crucially important neurological complications may occur in novel coronavirus infection. Even though based on some evidence, neurological complications are thought to be directly associated with novel coronavirus disease rather than being accidental, it is still theoretical with such limited data. Nevertheless, it must be taken into consideration when inquiring about neurological manifestations in patients with COVID-19.

Peer Review: Externally peer-reviewed.

Informed Consent: Written consent was obtained from the participants.

Author Contributions: Conception/Design of Study- P.V., M.K.; Data Analysis/Interpretation- P.V., M.K.; Drafting ManuscriptP.V., M.K.; Critical Revision of Manuscript- P.V., M.K.; Final Approval and Accountability- P.V., M.K.

Conflict of Interest: Authors declared no conflict of interest.

Financial Disclosure: Authors declared no financial support.

Hakem Değerlendirmesi: Dış bağımsız.

Bilgilendirilmiş Onam: Katılımcılardan bilgilendirilmiş onam alınmıştır.
Yazar Katkıları: Çalışma Konsepti/Tasarım- P.V., M.K.; Veri Analizi/Yorumlama- P.V., M.K.; Yazı Taslağı- P.V., M.K.; Iç̧eriğin Eleştirel Incelemesi- P.V., M.K.; Son Onay ve Sorumluluk- P.V., M.K.

Çıkar Çatışması: Yazarlar çıkar çatışması beyan etmemişlerdir.

Finansal Destek: Yazarlar finansal destek beyan etmemişlerdir.

\section{REFERENCES}

1. Uğraş Dikmen U, Kına M, Özkan S, İhan M. COVID-19 Epidemiyolojisi: Pandemiden Ne Öğrendik. J Biotechnolojy and Strategic Health Researche 2020;4:28-36. [CrossRef]

2. Wang HY, Li XL, Yan ZR, Sun XP, Hun J, Zhang BW. Potential neurological symptoms of COVID-19. Ther Adv Neurol Disord 2020;13:1-2. [CrossRef]

3. Sharifi-Razavi A, Karimi N, Rouhani N. COVID-19 and intracerebral haemorrhage: causative or coincidental? New Microbes New Infect 2020;35:100669. [CrossRef]

4. Tsai ST, Lu MK, San S, Tsai CH. The Neurologic Manifestations of Coronavirus Disease 2019 Pandemic: A Systemic Review. Front Neurol 2020;11:498. [CrossRef]

5. Mao L, Jin H, Wang M, Hu Y, Chen S, He Q, et al. Neurologic Manifestations of Hospitalized Patients With Coronavirus Disease 2019 in Wuhan, China. JAMA Neurology 2020;77(6):683-90. [CrossRef]

6. Ahmad I, Rathore FA. Neurological manifestations and complications of COVID-19: A literature review. J Clin Neurosci 2020;77:8-12. [CrossRef]

7. Li J, Long X, Zhu C, Lin Z, Li J, Xiong N, et al. A case of COVID-19 pneumonia with cerebral hemorrhage. Thromb Res 2020;193:22-4. [CrossRef]

8. Baig AM, Khaleeq A, Ali U, Syeda H. Evidence of the COVID-19 virus targeting the CNS: tissue distribution, host virus interaction, and proposed neurotropic mechanisms. ACS Chem Neurosci 2020;1;11(7):995-8. [CrossRef]

9. Tan YK, Goh C, Leow AST, Tambyah PA, Ang A, Yap ES, et al. COVID-19 and ischemic stroke: a systematic review and meta-summary of the literature. J Throm Thrombolysis 2020;50(3):587-95. [CrossRef]

10. Hemasian H, Ansari B. First case of Covid-19 presented with cerebral venous thrombosis: A rare and dreaded case. Rev Neurol (Paris) 2020;176(6):521-3. [CrossRef]

11. Bhatia R, Srivastava MVP. COVID-19 and Stroke: Incidental, Triggered or Causative. Ann Indian Acad Neurology 2020;23(3):318-24.

12. Moriguchi T, Harii N, Goto J, Harada D, Sugawara H, Takamino $J$, et al. A first case of Meningitis/Encephalitis associated with SARS-Coronavirus-2. Int J Infect Dis 2020;94:55-8. [CrossRef]

13. Levi M, Thachil J, Iba T, Levy JH. Coagulation abnormalities and thrombosis in patients with COVID-19. Lancet Haematol 2020;7(6):438-40. [CrossRef]

14. Morotti A, Goldstein JN. Diagnosis and Management of Acute Intracerebral Hemorrhage. Emerg Med Clin North Am 2016;34(4):883-99. [CrossRef]

15. Benger M, Williams $O$, Siddiqui J, Sztriha L. Intracerebral haemorrhage and COVID-19: Clinical characteristics from a case series. Brain Behav Immun 2020;88:940-44. [CrossRef]

16. Cheruiyot I, Sehmi P, Ominde B, Bundi P, Mislani M, Ngure $B$, et al. Intracranial hemorrhage in coronavirus disease 2019 (COVID-19) patients. Neurol Sci 2020;3:1-9. [CrossRef] 